This is an Accepted Manuscript of an article published by Taylor \& Francis in Early Child Development and Care on 19/10/16, available online:

https://www.tandfonline.com/doi/full/10.1080/03004430.2016.1237563 


\section{Inquiry Based Learning: A framework for assessing science in the Early Years (FASEY).}

\section{Introduction}

This paper explores the role of inquiry based learning in the early years, highlighting the benefits and challenges of using this approach with young children. A review of literature and research within inquiry based learning leads us to the development of an open ended pedagogical assessment known as the Framework for Assessing Science in the Early Years (FASEY) Model and Framework for Assessing Science in the Early Years (FASEY) Tool. Although the model and tool is derived from theoretical engagement, it is yet to be tested and trialled by early years practitioners in schools and settings. The trialling of the FASEY Model and FASEY Tool will form the basis for our next research project.

In order to trace the grass root problems of science education in the early years it is essential to understand the macro picture of England in terms of attainment levels in science which highlights the disconnect between initiatives at National Level and the practice with the youngest children within the continuum of education. Trends in International Maths and Science Study (TIMSS) is managed and coordinated by The International Association for the Evaluation of Educational Achievement (IEA) an independent cooperative with a membership of over a 70 countries. TIMSS studies the attainment levels of students across countries which offer a similar curriculum. The findings of 2011 suggest that Year Five students in England showed a decline in Science attainment from the year 2007 to the year 2011. Countries participating in TIMSS follow guidelines and strict sampling targets to provide samples that are nationally representative (Martin et al, 2012). The key stage two curriculum in England was featured to have less of the specific content that was studied by TIMMS however we were not inferior in the curriculum we offered to students and were in a much better position in terms of subject content than other high performing countries who participated in TIMMS (Martin et al, 2012). However the decline of student achievement in science raises multiple questions around the effectiveness of pedagogical approaches including assessment systems. Are we missing crucial opportunities to measure scientific inquiry in the most crucial years of rapid growth and development in young children? Brooker et al (2010) identified in a report commissioned by the Department for Education to review practitioner's experiences of the Early Years Foundation Stage that assessment practices were problematic and fraught with discrepancies between expected outcomes and actual learning. The report further reiterated that early years practitioners did not find the current assessment practices befitting of recording the learning of young children. We argue that current assessment systems fail to sufficiently highlight and capture the innate nature of scientific inquiry in individuals from a young age. We propose a model and tool for recording inquiry based learning. This we hope will help pedagogues as well as children to appreciate their ever evolving skills in developing scientific knowledge. 
However, it must be recognised that assessment practices have been debated and changes continually made to these; Lilly et al (2014) identify alternative assessment approaches developed by teaching schools within in their report on Beyond Levels. Internationals indicators such as the Programme for International Student Assessment (PISA) (Bradshaw, 2012) which focussed on Science in Key Stage Four identified the UK as above average in science performance when compared to the other OECD countries (Bradshaw, 2012) suggesting that changes to assessment systems are beginning to show results. PISA tests the skills and knowledge of 15-year-old students internationally in order to provide data and evaluate the education systems of its participants. To date, students representing more than 70 economies have participated in the assessment. Whilst this gives us the trends around the teaching and learning of science, it focusses on children who are older. Drawing on this evidence from PISA (Bradshaw, 2012) we maintain that children's learning and enthusiasm for science should be recognised, honed and recorded in the early years as it provides children the platform to build and develop scientific knowledge, skills and understanding. Recent studies on early years have highlighted and captured the importance of supporting children to be little scientists.

An initiative named the Creative Little Scientist (CLS) project, a 30 month EU funded study was carried out in nine countries including Belgium, Finland, France, Germany, Greece, Malta, Portugal, Romania and the UK. Children aged three to eight took part in the study which aimed to derive the policy and practice related to science and mathematics within these countries (Agogi, Rossis, and Stylianidou, 2014). The CLS Executive Summary concluded that European Education policy clearly acknowledged the study of science as crucial within early childhood however it also cited the disconnect between policy and practice (Agogi, Rossis, and Stylianidou, 2014). The CLS project noted that policy and pedagogical practice has yet to fully acknowledge very young children's capacity to be creative little scientists, capable of developing reasoned and critical thinking about the world they live in.

In England, science is not a discrete subject within the Early Years Foundation Stage (EYFS) (DfE, 2014) but is placed within the 'Understanding the World' area of learning with the broad aim of 'guiding children to make sense of their physical world and their community through opportunities to explore, observe and find out about people, places, technology and the environment' (DfE, 2014:8). In addition to this, value is placed on the learning dispositions of 'Play and Exploration', 'Active Learning' and 'Creativity and Critical Thinking' (DfE, 2014:9). These characteristics have been identified in studies such as the Effective Provision of Pre-School Education (EPPE) Project (Sylva et al, 2004) which will be discussed later. The Early Learning Goal that is set for the end of the Reception year within the EYFS (DfE, 2014) expects children to know about their immediate environment in terms of places, objects, materials and living things; identifying similarities, differences and change. It could be argued that the definition of science within the EYFS is narrow and is not always identifiable in the teaching, learning and assessment practices within early years setting (Davies et al, 2014). This has led us to consider a framework for assessing which can provide early 
years practitioners with some guidelines to extend their understanding of science inquiry.

According to Eshach and Fried (2005) children need to learn science to understand how the world that they live in works and to develop their critical thinking skills about everyday phenomenon. It is therefore essential for us to define the scientific domains which form the backdrop for discussions within this article. According to Zimmerman (2000) science can be categorised into 'Domain Specific Knowledge' and 'Domain General Knowledge'. The former refers to the fact that the world is understood through many independent specialised knowledge structures about the natural and physical world (Zimmerman, 2000). The latter suggests that the understanding of science is derived from experiential learning that does not necessarily stem from a scientific source and is transferable from one domain to the next. The CLS (Agogi, Rossis, and Stylianidou, 2014) project discusses the validity of engaging children in Domain General Knowledge which builds them towards the comprehension of Domain Specific Knowledge.

\section{Domain Specific Knowledge}

Domain Specific Knowledge relates to explicit categories of science which includes elements of Biology, Chemistry and Physics and the specialised concepts that exist within each domain (Eshach and Fried, 2005). By engaging in Domain Specific Knowledge children begin to understand the real world they live in. However, Einstein and Infeld (1938) claim that science is not about the real world. Driver and Bell (1986) argue that in order for children to understand the phenomenas in the real world, they need to study it through the lenses of a scientific framework. They argue young children may not be at an age of maturity to understand the independent specialised knowledge structures for example concepts such as gravity and force (Driver and Bell, 1986). These theories are part of the real world that children live in, however they are abstract concepts, not readily evident to the observing child. Eshach and Fried (2005) maintain that concepts have to be learnt with the Domain Specific Knowledge in order for us to understand the laws, theories and phenomena in a scientific way. It pairs knowledge of theory and knowledge of evidence together to offer us a logical understanding of the world (Eshach and Fried, 2005). If these concepts of science are simplified, argues Gardner (1999) children will develop misconceptions. Black and Harlen (1993) point out that exposing children too early to scientific concepts can lead to misconceptions that can cloud their ability to understand Domain Specific Knowledge as misconceptions are hard to unlearn. Are children in the early years ready to engage in Domain Specific Knowledge? If we study science in the early years from a Domain Specific Knowledge, then children are constantly having misconceptions about the world that they live in? Is the underpinning knowledge of theory and concepts of the real world essential in early childhood? Is early childhood the appropriate platform for learning science? Should science be introduced when children are more mature and mentally ready to engage with more abstract concepts which would then give them the logical picture of the real world that they live in? 


\section{Domain General Knowledge}

Domain General Knowledge refers to transferable skills that can be used across a range of disciplines both scientific and non-scientific. It involves proficiencies such as observation, questioning, choosing the appropriate resources, measuring, recording, making inferences, developing conclusions and a range of other competences that form the bedrock for cultivating reasoning skills (Eshach and Fried, 2005). This aspect of science is concerned with the inquiry and reasoning skills derived from questions about the real world as well as the interpretations and the conclusions that originate from engagement with the real world (Driver and Bell, 1986). This forms a natural platform for the development of science in early childhood because children are intrinsically curious (National Science Teachers Association, 2014). They are natural investigators and, with some guidance, are in the right place to interpret the real world that they live in through their observations and experiential learning processes which often takes place during play.

\section{Play}

Play is seen as the core vehicle to learning for young children (Craft, 2002). It has been widely acknowledged that play enables children to explore, make connections and build on existing knowledge and understanding of their world (Dewey, 1910; Isaacs, 2006; Cremin et al, 2014). Play provides the platform for investigating materials and resources, testing ideas, reasoning and co-constructing knowledge (Woods, 2016). Although pedagogues recognise the value and role of play, their confidence and competence often become the barrier towards stimulating early scientific learning through play (Hardman and Riordan, 2014; Harlan and Rivkin, 2012). When developing the FASEY model, we value play as the kinesis that gives momentum to inquiry based learning. Therefore, play forms a horizontal cyclical flow which starts from the stimulus right through to the outcome within the FASEY model.

McLean, Jones and Schaper (2015) assert that the synergy between play based pedagogies and inquiry based learning provide the ideal platform for learning science in the early years. The development of communication and social skills in early years often leads to exploration, investigation, questioning, prediction, negotiation, discussions, reasoning and problem solving which builds a strong link with science based learning (Fellowes and Oakley, 2010). Jurow and Creighton (2005) go on to suggest that the insights children get from their active explorations during play develops their knowledge of scientific concepts, leading children to form hypotheses, theories and rationales which are the building blocks for Domain Specific Knowledge.

\section{Practitioner's Knowledge and Skills}

However, practitioners within the early years often lack both the knowledge and skills to make the crucial links between curriculum development areas such as language 
and communication and children's natural curiosity and investigative skills (Siry and Kremer, 2011). As a result critical periods to support young children's episodes of scientific exploration are missed (Siry and Kremer, 2011). Gerde, Schachter and Wasik (2013) confirm that teaching practice and resources within the classroom do not facilitate high quality science experiences. Early et al. (2010) draw attention to the fact that there is less focus on science compared to other domains of learning within the early years due to the low esteem and lack of subject knowledge amongst practitioners working in this phase of learning. Apart from practitioners' knowledge and skills, the paucity of scientific based inquiry learning can also be attributed to the differing personal experiences and attitudes of early years practitioners with regards to science. Some view science as facts, knowledge, laws and experiments whilst others subscribe to the 'process-based' model which recognises that 'science and knowledge is shifting and tentative - inherently rooted in the 'here and 'now' of everyday things and events' (Davies et al, 2014:7). These elements of knowing and doing are interlinked but it can be argued that children in the early years are at a developmental stage where 'attitudinal' and 'procedural' knowledge (Davies \& Howe, 2003:102) are the most appropriate starting points. Brunton and Thornton (2010) argue that most young children have not yet developed the reasoning and mental visualisation skills required to understand complex scientific concepts, however they can actively investigate through play to refine their understanding and practitioners must skilfully facilitate this process.

\section{Personal, Social and Emotional Development}

Inquiry based learning supports children specifically in their scientific learning but also provides them with the attitudes and skills that make them life- long learners with a heightened understanding of their identity and place within their microsystem, mesosystem, exosystem and macrosystem (Bronfenbrenner, 1979). Rogers (1983) argues that the personal involvement of the learner and the excitement that they can gain from self-initiated learning can support the development of their emotional and social wellbeing (cited in Woods, 2016). This then perpetuates the learning as the child develops the confidence to seek meaning alongside others and to take risks with their scientific exploration and theory-making; attaining 'self-actualisation' (Maslow, 1954). Often these dispositions towards learning are not recorded when practitioners record outcomes related to science. Science is rarely represented alongside personal, social and emotional development within the early years however the CLS (Cremin et al, 2014) project draws heavily on confident children as engaging little scientists capable of driving their own learning. The FASEY tool highlights PSED outcomes alongside Communication and Cognitive Indicators as it celebrates the relationship of both aspects in promoting scientific inquiry.

\section{Socio Cultural Perspectives}


According to Nolan and Kildery (2010: 113) 'children are viewed as competent, socially active learners who are able to co-construct their learning intentions, learning strategies and learning outcomes in culturally meaningful ways with peers and adults'. Leaning on this concept, we believe that inquiry based learning is best situated within a social cultural paradigm.

The Effective Provision of Pre-School Education (EPPE), which proved to be an influential longitudinal study of a national sample of young children's development carried out through a case study analysis of 12 effective pre-schools from a larger sample of 141 settings carried out between 1997 to 2003 highlights the effectiveness of learning rooted in socio cultural frameworks (Sylva et al, 2004). Researchers observed that some of the most effective pedagogies in the early years were based on Vygotskian perspective of socio cultural paradigms of learning where children were co-constructors of knowledge (Siraj-Blatchford, 2009). Children explored naturally occurring phenomenon through 'Sustained Shared Thinking' (SST) which SirajBlatchford (2009: 78-79) defines as 'an effective pedagogic interaction, where two or more individuals work together in an intellectual way to solve a problem, clarify a concept, evaluate activities or extend a narrative'. In the EPPE study, play is reported to encourage rich episodes of SST (Sylva et al, 2004). SST promotes personal, social and emotional development as well as positive cognitive outcomes (Purdon, 2016). Piaget's (1969) theory of assimilation, disequilibrium and accommodation in particular establishes the child as an active problem solver with 'cognitive powers' (Woods, 2016:13). This leads to the argument that the young child already has many of the dispositions required of a scientist that can be nurtured and developed within a social context. This concept is not new and has been continually advocated by the pioneers of early childhood as well as international perspectives such as Reggio Emilia that position the competent and capable child alongside significant others "as an architect of their own learning" (Dodd-Nufrio 2011: 236). The problem according to RobertsHolmes (2014) lies with the assessment practices in early years that fail to capture socially constructed learning and knowledge.

\section{FASEY}

Prior to unpacking FASEY both as a pedagogical model and tool, it is essential to identify the current attitudes towards the teaching of science. In order to do this, we will be 'anchoring one foot inside a sociocultural frame, while allowing the other foot to move around into other conceptual terrain' (Guttierrez, 2007, cited in Carr et al, 2010:2). It is also important to consider the ground that lies between learning dispositions and curriculum design (Carr et al, 2010). Science education is often content based, with the long-term view of children developing predetermined aspects of knowledge and understanding of their world, sometimes to the detriment of learning dispositions such as curiosity and drive (Woods, 2016). Knowledge is arguably an essential part of learning, however, as Goodnow (cited in Carr, 2010: xii) states, our aim is not to "end with children who are "able" in school terms and are physically present but have no sense of "engagement" with what is happening in class or with 
any "learning" situation". It is important therefore to explore "trajectories of learning in the making" (Carr et al, 2010:15) and to identify how children can engage with deep learning processes through intrinsic motivation and socialisation. Laevers (2005) argues that children can develop this learning through creativity, flexibility and reflection, whilst Bertram and Pascal (2002) identify independence, creativity, selfmotivation and resilience as being key dispositions of effective learners. Carr et al (2010) however focus their discussions on reciprocity, resilience and imagination as drivers for meaningful learning. Drawing on this literature, we have identified the thematic components within FASEY and aim to capture these complex processes. Although it starts with the stimulus, it also provides an avenue to recognise and characterise the co-construction processes, the indicators of success as well as the outcomes of learning.

James et al (1998, cited in Gripton, 2016:110) refer to children as a 'distinct tribe'; we cannot assume knowledge of how they think, act, communicate or learn. When assessing children's learning it is important to access their lived experience of 'layered emotions, actions and conceptions' (Londal, 2010:393). If an Inquiry Based teaching and learning model is valued and used in the early years, there are implications for assessment which need to be explored. The real longer term outcomes become our focus and the process of learning becomes more important than the attainment of specific goals. Laevers (2002:9) challenges 'an overreliance on educational outcomes' citing the fact that practitioners are often under pressure to raise levels and demonstrate achievement in specific terms. The findings of the Creative Little Scientists project (Agogi, Rossis, and Stylianidou, 2004) confirmed this, identifying that there is limited assessment of young children's inquiry processes, procedural understanding and the social dimensions of learning.

In reconceptualising the learning of Science in the Early Years, we recognised the need to introduce an assessment model and accompanying tool that is both open ended and comprehensive to record the various ways in which children demonstrate scientific inquiry skills. The information that FASEY hopes to capture sits mainly within the Domain General Knowledge. FASEY provides a simple model which gives an overview of the entire process involved in assessing and recording scientific inquiry process. This is accompanied by a checklist of cues (see Appendix 1) which practitioners can use as a guide to record inquiry based learning or occurrences. The model begins with the stimulus, leading to the next theme which is co-construction of knowledge (adult with child, peer to peer), indicators of success and outcomes which practitioners can identify in a variety of ways. 


\section{FASEY MODEL}

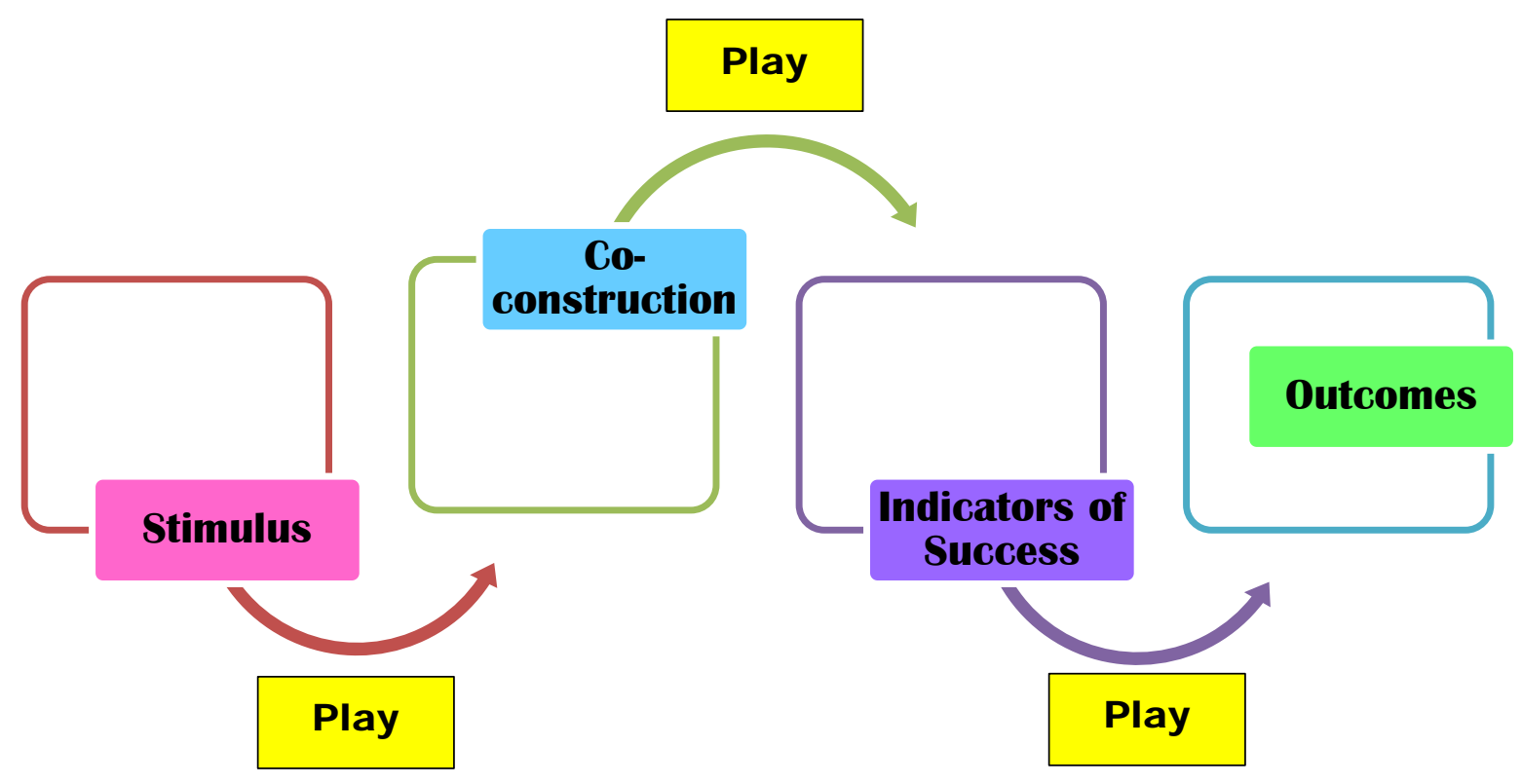

Figure 1: FASEY MODEL

The FASEY model is linear and is driven by inter-related and inter-dependent processes, represented as a horizontal spiral of learning which has starting points and outcomes. In this model we encourage practitioners to identify a starting point and to record the process of learning (co-construction of knowledge) which leads to outcomes. This is recorded in a linear manner so we distinguish the threads and processes of thinking that children demonstrate during inquiry based learning. Play provides the cyclical thread between the various processes. Winsler and Carlton (2003) argue that play becomes problematic when the need for adult intervention is required to support learning especially in injecting knowledge and clarifying misconceptions. O'Brien (2010) suggests that adult intervention during play can damage children's intrinsic motivations to learn. However, Wood (2013) offers us a balanced solution that play should accommodate both child centred activity and adult interventions. The FASEY model accommodates the differing viewpoints on play.

\section{FASEY: Stimulus}

The stimulus records child initiated experiences and covers areas such as children's current interests, life events, children's ideas that stem from their curiosity, their reflections and their cultural encounters. Children's natural curiosity provides the 
themes for inquiry which practitioners need to quickly recognise, capture and document. These themes provide a springboard for further exploration and investigation which we discuss in the next section. Whilst we recognise the value of child initiated learning, FASEY also offers the flexibility of recording adult led or thematic activities which could be an alternate stimulus for the child's active exploration. According to Pramling Samuelson and Johannson (2009) taking on board children's perspectives and using them as the foundation to launch learning is problematic because of ratios and time constraints to engage in meaningful observations. Equally, where learning dispositions are fragile, adults within the environment may need to invite learners to participate, to actively engage and to recognise opportunities that are new and potentially exciting (Carr and Claxton, 2004). It is in instances such as these that the FASEY tool withstands the test of barriers as it provides the flexibility and adaptability to record adult led or adult initiated stimulus, child led or child initiated stimulus as well as any other motivation that the practitioner identifies as the starting point of inquiry based learning.

\section{FASEY: Co-Construction}

The nature of children's learning which is rooted in socio cultural perspectives based on engagement with the social environment and co-construction of knowledge provides a rich platform for scientific exploration (McLean, Jones and Schaper, 2015). Siry and Kremer (2011) argue that it is complex to capture children's scientific knowledge because children construct knowledge through their personal observations of phenomenon or the co-construction of knowledge through their engagement with peers. Siry and Kremer (2011) go on to argue that often concepts that emerge in early childhood are abstract and complex and practitioners often struggle to facilitate learning of these concepts. The FASEY tool supports practitioners to identify and break the concepts of learning down into smaller observable components. It is hoped that by sub-dividing these observable components of co-construction, practitioners will be better positioned to extend their learning through play (Nolan and Kildery, 2010).

Encouraging children to 'explore possible worlds' (Carr et al, 2010:143) through multimodality representation can enable them to continually adapt and redesign their ideas in order to explore and understand scientific concepts. Through 'storying selves' (Carr et al, 2010: 171) the notion of identity is developed through sharing experiences in time and in relation to others. Making these connections can impact on children's understanding of the world around them. As practitioners we need to find ways to enable and excite this learning, at times participating alongside the child as a coconstructor (Brunton and Thornton, 2010). 'Provocations' are used within the Reggio Emilia approach to challenge children's thinking and stimulate long-term investigations and discoveries (Brunton and Thornton, 2010). Open-ended questioning and sustained shared thinking (Sylva et al, 2004) are tools that enable the practitioner to develop meaning alongside the child, whilst allowing him to take the initiative, think for himself and bring his unique interpretation of the world to the learning experience. By 
using the FASEY tool, practitioners can capture these rich moments of scientific engagement.

Inquiry based learning does not rely on the child giving the 'correct' answer; indeed their full understanding may not develop for several years. It can be argued that these potential 'misconceptions' (Allen, 2014) will impact negatively on their scientific knowledge. However, Robson (2006:137) argues that real scientists go through this process themselves and a more suitable terminology might be 'alternative frameworks' that the children are working within. The FASEY tool provides the practitioner with an ongoing record of how children are developing concepts and/or refining their misconceptions. Through probing questions the adult can support the child to investigate further and clarify meaning. It is important to keep in mind Dewey's (1910:33-34) belief that 'the teacher usually has more to learn than to teach...to keep alive the sacred spark of wonder and to fan the flame that already glows'. As in the Reggio Emilia approach, children can be challenged to use words, drawings, play or drama to 're-visit, re-view and re-present' their thinking (Brunton \& Thornton, 2009: 72). The adult might suggest the correct explanation during discussion but this would be presented as an option to be considered, thus continuing to value the child's own explanations and theories; scientific vocabulary might also be modelled at this time (Brunton \& Thornton, 2010).

\section{FASEY: Indicators of Success}

Drawing on the Leuven Involvement Scales (Laevers, 1994), we recognised the need to include a set of signals which showcase children's personal, social and emotional development as well as their cognitive and language development. These indicators are the precursors to deep level learning. The indicators of success provide the practitioner with a guide to recognise the skills which children use to make connections between knowledge and experiences which form the platform for higher order thinking skills (Eshach and Fried, 2005). Responsibility is shared, other perspectives are heard and the child values 'being' and 'becoming' a group member (Carr et al, 2010:14). Through this social interaction children can explore 'living in the middle', adapting, editing, re-contextualising, enjoying and constructing (Wertsch, 1998:65) with different learning partners and within different social arrangements; leading to a rich and valuable learning experience (Cowie and Otrel-Cass, 2011). This 'community of practice' (Wenger, 1998) enables children and adults to recognise alternative learning trajectories and to move away from the confines that the science curriculum may well present. Within a social cultural ethos, the FASEY tool enables practitioners to record children's resilience in having a go at new things, raising questions, negotiating, clarifying information, problem solving and evaluating. This is drawn from (Brunton and Thornton, 2010).

\section{FASEY: Outcomes}


Edelman (1992, cited in Davies et al, 2014:17) states that the brain resembles 'the sound and light patterns and the movement and growth patterns of the jungle'. As children are challenged by materials or phenomena, connections are made in the neurological networks of the brain thus enabling them to develop more abstract understanding (Davies et al, 2014). When the mind is 'ready, willing and able' (Carr et al, 2010:15) learning power is at its optimum as young children will know why, when and how to use their knowledge and ability. Smiley and Dweck's research (1994) found that many 4 year olds were more concerned with performance and attaining goals than they were with the process of learning. It is arguable that this is a possible outcome of the current Early Years Statutory Framework (DfE, 2014) where the 'fixed mindset' might be in opposition to the 'growth mindset' (Dweck, 2006, cited in Carr et al, 2010:28). This in turn can impact on the resilience of our young children, their confidence to explore, take risks within their learning and apply knowledge to new situations.

The FASEY Outcomes are divided into Personal, Social and Emotional Dispositions (PSED) as well as Communication and Cognitive Indicators ( $\mathrm{CCl}$ ). This gives the practitioner the opportunity to identify the child's evolving knowledge and skills within communication and cognitive domains whilst highlighting their PSED. The focus of PSED in FASEY draws on our literature on social cultural perspectives which we have discussed earlier. Within a social cultural perspective, thinking and knowledge are anchored in societal practices and interactions (Fleer, 2009). This led us to group the FASEY outcomes into PSED and CCI. The FASEY tool complements the EYFS (DfE, 2014) which cements personal, social and emotional development as well as communication and language as prime areas of learning; the cognitive elements are embedded throughout the seven areas of learning and development (DfE, 2014). According to Piaget (1959) and Chomsky (2006) cognitive ability is closely linked to communication and language development as children continuously interact with people and their immediate environment. Within the $\mathrm{CCl}$, children's ability to interpret the evidence and link it to other theories or schemas is recorded as an outcome; Eshach and Fried (2005) classify this as developing new knowledge.

\section{Conclusions and Recommendations}

The FASEY Model and the FASEY Tool have been derived through the engagement with literature on child development, assessment practices, socio cultural perspectives and scientific knowledge. Although it has not been trialled in early years settings, the adaptability and the flexibility of the Model and Tool hopefully provides the readers with starting points for deeper reflections around the importance of documenting inquiry based learning to extend scientific engagement and interest. The design of the FASEY Model and Tool promotes the opportunity to situate personal, social and emotional dispositions alongside communication and cognitive indicators, recognising the crucial relationship between both throughout the process 
of inquiry based learning rooted in a socio cultural perspective. We intend to extend our investigation of effective strategies to support scientific based inquiry by applying the FASEY Model and implementing the FASEY Tool within early year's settings. It is hoped that the trials will shed further light on how the Model and the Tool can be advanced or reconceptualised to enable science in the Early Years to observed and recorded more effectively. 


\section{References}

Agogi, E., Rossis, D. and Stylianidou, F. (2014) Creative Little Scientists: Enabling Creativity through Science and Mathematics in Preschool and First Years of Primary Education. Available at: http://www.creative-little scientists.eu/sites/default/files/D6 6 Recommandations to Policy Makers and Stakeholders FINA L.pdf (accessed: 8.5.16).

Allen, M. (2014) Misconceptions in Primary Science. Maidenhead: Open University Press.

Bertram, T. and Pascal, C. (2002) 'What counts in early learning?', in Saracho, O.N. and Spodek, B. (eds), Contemporary Perspectives in Early Childhood Curriculum. Greenwich, CT: Information Age, pp. 241-256.

Black, P., and Harlen, W. (1993). 'How can we specify concepts for primary science?', in Black, P. J., and Lucus, A. M. (Eds.) Children's Informal Ideas in Science. London: Routledge, pp. 208-229.

Bradshaw, J. (2012) Programme for International Students Assessment (PISA) Results from Pisa 2012. United Kingdom. Available at: http://www.oecd.org/pisa/keyfindings/PISA-2012-results-UK.pdf (accessed: 5.5.16).

Brooker, L., Rogers, S., Ellis, D., Hallet, E. and Roberts-Holmes, G. (2010) Practitioners' Experiences of the Early Years Foundation Stage. Runcorn: Department for Education.

Bronfenbrenner, U. (1979) The Ecology of Human Development. MA: Harvard University Press.

Brunton, P. and Thornton, L. (2010) Science in the Early Years. London: Sage.

Carr, M., Smith, A.B., Duncan, J., Jones, C., Lee, W. and Marshall, K. (2010) Learning in the Making. Rotterdam: Sense Publishers.

Claxton, G \& Carr, M, 2004, 'A framework for teaching learning: the dynamics of disposition'. Early Years, vol 24 (1)., pp. 87 - 97

Chomsky, N. (2006) Language and Mind. Cambridge: Cambridge University Press.

Cowie, B. and Otrel-Cass, K. (2010) 'Exploring the value of 'horizontal' learning in early years science classrooms', Early Years: An International Research Journal, vol. 31(3), pp. 285-295.

Craft, A. (2002) Creativity and Early Years Education: A lifewide foundation. London: Continuum.

Cremin, T., Glauert, E., Craft, A., Compton, A. and Stylianidou, F. (2014) 'Creative little scientists: exploring pedagogical synergies between inquiry based and creative approaches in Early Years science', Education 3-13, vol. 43 (4), pp.404-419.

Davies, D., Collier, C., Digby, R. Earle, S. and McMahon, K. (2014) Teaching Science and Technology in the Early Years (3-7) (2nd edn.) Abingdon: Routledge.

Davies, D. and Howe, A. (2003) Teaching Science and Design Technology in the Early Years. London: David Fulton.

Department for Education (2014) Statutory framework for the Early Years Foundation Stage. Setting the standards for learning, development and care for children from birth to five. Runcorn: DfE.

Department for Schools Children and Families (2008) Statutory Framework for the Early Years Foundation Stage. Available at: http://webarchive.nationalarchives.gov.uk/20130401151715/http://www.education.gov.uk/publications/ eOrderingDownload/eyfs res stat frmwrk.pdf (accessed: 6.5.16).

Dewey, J. (1910) How we Think. Boston: DC Heath. 
Driver, R. and Bell, B $(1986)$ 'Students' thinking and the learning of science: A constructive view', School Science Review, vol. 67, pp. 443-456.

Dodd-Nufrio, A.T. (2011) 'Reggio Emilia, Maria Montessori, and John Dewey: Dispelling teachers' misconceptions and understanding theoretical foundations', Early Childhood Education Journal, 39(4), pp.235-237.

Early, D. M., Iruka, I.U., Ritchie, S., Barbarin, O. A., Winn,D. M. C. and Crawford, G. M. (2010) 'How do pre- kindergarteners spend their time? Gender, ethnicity and income as predictors of experiences in pre-kindergarten classrooms.' Early Childhood Research Quarterly, vol 25. pp. 177-193.

Einstein, A. and Infeld, L. (1938) The Evolution of Physics. New York: Simon and Schuster.

Eshach, H., \& Fried, M. N. (2005). 'Should science be taught in early childhood?', Journal of Science Education and Technology, vol.14, pp. 315-336

Fellowes, J., \& Oakley, G. (2010). Language, literacy and early childhood education. South Melbourne, VIC: Oxford University Press.

Fleer, M. (2009) 'Supporting Scientific Conceptual Consciousness or Learning in 'a Roundabout Way' in Play-based Contexts', International Journal of Science Education, vol. 31 (8), pp. 1069-1089.

Gardner, H. (1999) The Disciplined Mind: What all students Should Understand. New York: Simon and Schuster.

Gerde, H. K., Schacter, R.E. and Wasik, B. A. (2013) 'Using the Scientific Method to Guide Learning: An Integrated Approach to Early Childhood Curriculum', Early Childhood Education Journal, vol. 41, pp. 315-323

Gripton, C. (2016) 'Nurturing involvement through assessment and planning for possibilities', in Woods, A. Examining Levels of Involvement. New York: Routledge, pp. 105-117.

Hardman, M. and Riordan, J. P. (2014), 'How might educational research into children's ideas about light be of use to teachers?', Physics Education, vol. 49, pp. 644-653.

Harlan, J., \& Rivkin, M. (2012). Science experiences for the early childhood years: An integrated affective approach (10th edn). Upper Saddle River, NJ: Pearson Education.

Issacs, B. (2006) Bringing the Montessori Approach to your Early Years Practice. London: David Fulton.

Jurow, A. S. and Creighton, L. (2005) 'Improvisational Science Discourse: Teaching Science in Two K1 Classrooms', Linguistics Education, vol.16, pp. 275-297.

Laevers, F. (1994) (ed.) The Leuven Involvement Scale for Young Children, LIS-YC. Manual. Leuven, Belgium: Centre for Experiential Learning.

Laevers, F. (2002) Research on Experiential Education: Reader. Leuven, Belgium: Centre for Experiential Learning.

Laevers, F. (2005) Deep-level Learning and the Experiential Approach in Early Childhood and Primary Education. Leuven, Belgium: Katholieke Universiteit Leuven, Research Centre for Early Childhood and Primary Education.

Lilly, J., Peacock, A., Shoveller, S and Struthers, D. (2014) Beyond Levels: alternative assessment approaches developed by teaching schools. Nottingham: National College for Teaching and Leadership.

Londal, K. (2010) 'Children's Lived Experience and Their Sense of Coherence: Bodily Play in a Norwegian After-School Programme', Child Care in Practice, vol. 16(4), pp. 391-407

Maslow. A. H. (1954) Motivation and Personality. New York: Harper. 
McLean, K., Jones, M. and Schaper, C. (2015) 'Children's literature as an invitation to science inquiry in early childhood education', Australasian Journal of Early Childhood, vol. 40 (4) p.49.

National Science Teachers Association (NSTA) (2014) NSTA Position Statement: Early Childhood Science Education. Available at: http://www.nsta.org/docs/PositionStatement_EarlyChildhood.pdf (accessed 8.5.16).

Nolan, A. and Kilderry, A. (2010) 'Postdevelopmentalism and professional learning: implications for understanding the relationship between play and pedagogy', in Brooker, L \& Edwards, S (eds) Engaging Play. Maidenhead: Open University Press, pp. 108-121.

O'Brien, L. (2010). 'Let the wild rumpus begin! The radical possibilities of play for young children with disabilities', in L. Brooker \& S. Edwards (eds.), Engaging play. Maidenhead: Open University Press pp.182-194.

Roberts-Holmes, G. (2015) 'The 'datafication' of early years pedagogy: 'if the teaching is good, the data should be good and if there is bad teaching there is bad data', Journal of Education Policy, vol. 30 (3), pp. 302-315.

Robson, S. (2006) Developing Thinking and Understanding in Young Children. London: Routledge.

Siry, C and Kremer, I. (2011) 'Children Explain the Rainbow: Using Children's Ideas to Guide Science Curricula', Journal of Science Education and Technology, vol. 20 (5), pp. 643-655.

Von Stumm, S., Hell, B. and Chamorro-Premuzic, T. (2011) 'The Hungry Mind: Intellectual Curiosity Is the Third Pillar of Academic Performance', Perspectives on Psychological Science, vol. 6 (6), pp.574588

Martin, M. O., Mullis, I. V. S., Foy, P. and Stanco, G. M. (2012) TIMSS 2011 International

Results in Science. Available at:

http://timssandpirls.bc.edu/timss2011/downloads/T11 IR Science FullBook.pdf (accessed 3.5.16).

Piaget, J. (1959) The Language and Thought of a Child. London: Routledge.

Piaget, J. (1969) The Psychology of the Child. New York: Basic.

Pramling Samuelsson, I. and Johansson, E. (2009) 'Why do children involve teachers in their play and learning?', European Early Childhood Education Research Journal, vol. 17(1), pp. 77-94.

Purdon, A. (2016) 'Sustained shared thinking in an early childhood setting: an exploration of practitioners' perspectives', Education 3-13, vol. 44(3), pp. 269-282.

Siraj-Blatchford, I. (2009) 'Conceptualising progression in the pedagogy of play and sustained shared thinking in early childhood education: A Vygotskian perspective', Educational and Child Psychology, vol. 26 (2), pp. 77-89.

Smiley, P. A. and Dweck, C. S. (1994) 'Individual differences in achievement goals among young children', Child Development, vol. 65, pp. 1723-1743.

Sylva, K., Melhuish, E., Sammons, P., Siraj-Blatchford, I. and Taggart, B. (2004) The Effective Provision of Pre-School Education (EPPE) Project: Final Report. Available at: http://eprints.ioe.ac.uk/5309/1/sylva2004EPPEfinal.pdf (accessed: 8.5.16).

Tickell, C. (2011) The Early Years: Foundations for life, health and learning. Available at: https://www.gov.uk/government/uploads/system/uploads/attachment data/file/180919/DFE-001772011.pdf (accessed 8.5.16).

Tytler, R. (2007). Re-Imagining science education: Engaging students in science for Australia's future. Camberwell, VIC: Australian Council for Educational Research (ACER). 
Wenger, E. (1998) Communities of Practice: Learning, Meaning and Identity. Cambridge: Cambridge University Press.

Wertsch, J. V. (1998) Mind as Action. New York: Oxford University Press.

Winsler, A. and Carlton, M. P. (2003) 'Observations of children's task activities and social interactions in relation to teacher perceptions in a child-centered preschool: Are we leaving too much to chance?' Early Education and Development, vol. 14 (2), pp. 155-178.

Wood, E. (2013) Play, learning and the early childhood curriculum (3rd edn.). London: Sage.

Woods, A. (2016) Examining Levels of Involvement. New York: Routledge.

Zimmerman, C. (2000) 'The development of scientific reasoning skills', Developmental Review, vol. 20, pp. 99-149. 


\begin{tabular}{|c|c|c|}
\hline ASPECT: STIMULUS & $\begin{array}{l}\text { OBSERVABLE SIGNALS } \\
\text { Identify and record the starting point } \\
\text { (stimulus) for an inquiry based } \\
\text { activity/event. }\end{array}$ & COMMENTS \\
\hline 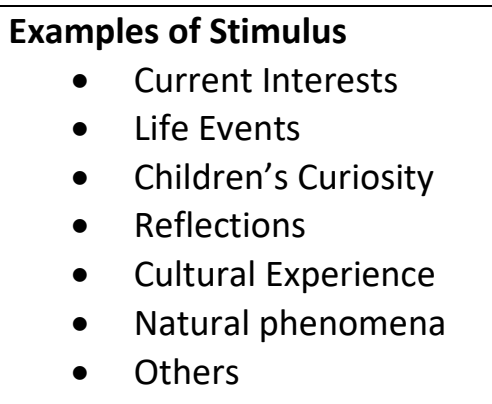 & & \\
\hline ASPECT: CO-CONSTRUCTION & $\begin{array}{l}\text { How does the child build on his/her } \\
\text { current inquiry based knowledge } \\
\text { through engagement with others (peers, } \\
\text { adults, social groups)? }\end{array}$ & \\
\hline $\begin{array}{l}\text { Examples } \\
\text { - Establishing a dialogue } \\
\text { - Observing } \\
\text { - Recording } \\
\text { - } \text { Questioning } \\
\text { - Siscussing } \\
\text { - Planning } \\
\text { - Predicting } \\
\text { - Offering explanations } \\
\text { - Making adaptations } \\
\text { - Clarifying } \\
\text { - } \text { misconceptions } \\
\text { - Pelf-assessment } \\
\text { - Others }\end{array}$ & & \\
\hline $\begin{array}{l}\text { ASPECT: INDICATORS OF } \\
\text { SUCCESS }\end{array}$ & $\begin{array}{l}\text { How are children demonstrating their } \\
\text { knowledge and learning dispositions? }\end{array}$ & \\
\hline $\begin{array}{ll}\text { Examples } \\
\text { - } \text { Focussing on Task } \\
\text { - } \text { things a go at new } \\
\text { - Investigating } \\
\text { - Clarifying Information } \\
\text { - } \text { Raising new questions } \\
\text { - Probluating } \\
\text { - Negotiating } \\
\text { - Association of key } \\
\text { - Taking turns } \\
\text { - Sharing } \\
\text { - Verbalising thoughts } \\
\text { - Working with others } \\
\text { - Persistence }\end{array}$ & & \\
\hline
\end{tabular}




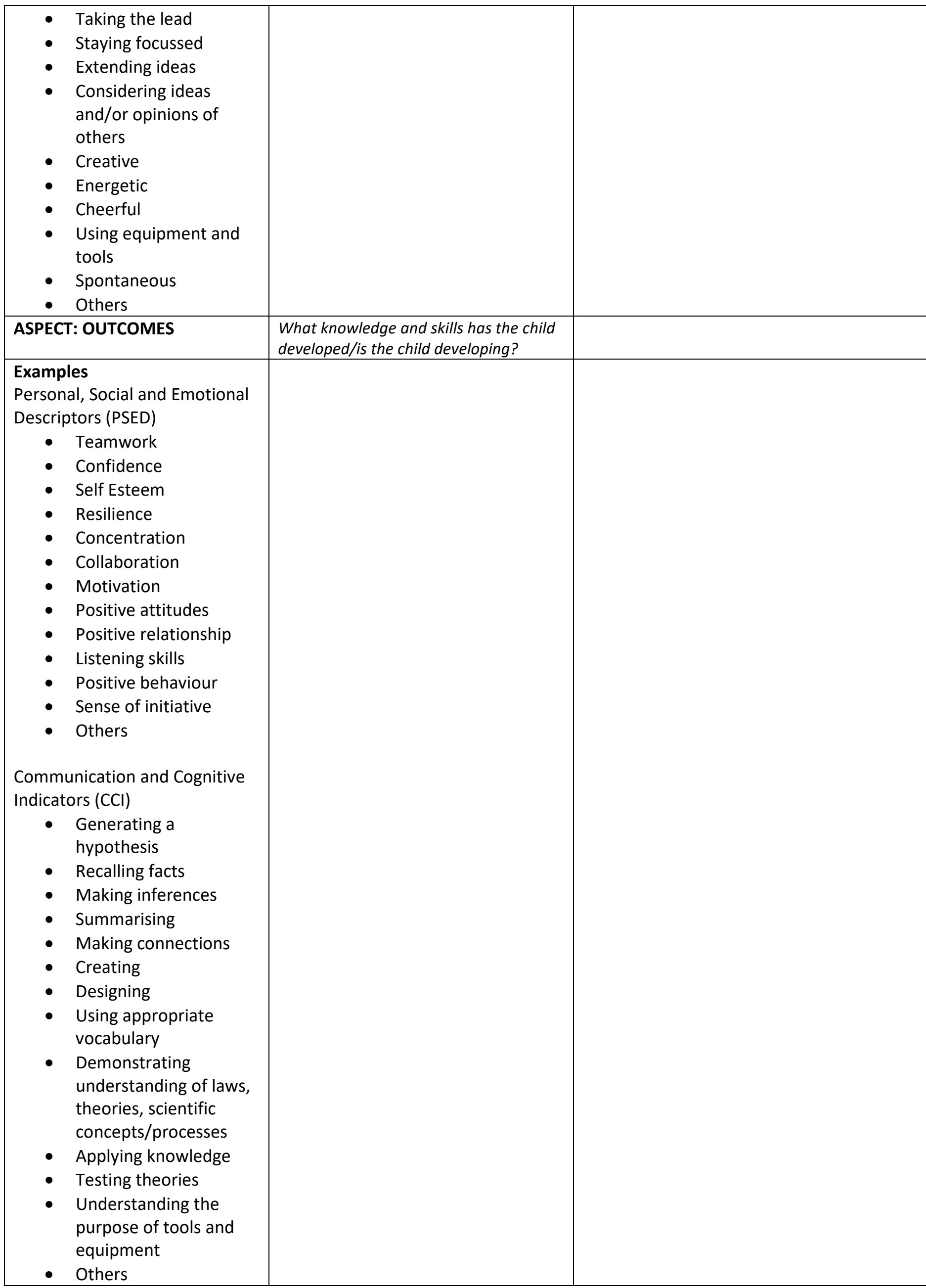

